\title{
Formação Progressiva do Direito Internacional Privado por Parte dos Juízes: \\ a Experiência Americana e Alemã até 1986*
}

\section{Prof. Dr. Dr. h.c. mult Erik Jayme}

Sumário: I. Introdução. - 1. Norma de conflito. - 2. Novas normas materiais e produção do direito internacional privado -3 . Fortbildung de normas matetiais estrangeiras por parte dos juízes alemães? - 4. Rechtsfortbildung e decisão baseada sobte a particularidade de cada caso -5 . Cláusulas de exceção - 6. Critérios. - II. O princípio da igualdade no Grundgesetz e a Rechtsfortbildung do diteito internacional de famlia. - 1. O direito internacional do divórcio.2. Direito internacional das relações patrimoniais entre cônjuges. - III. O direito internacional da ilicitude civil. -1 . Seguto no mesmo Estado e residência habitual comum no mesmo Estado. -2. Relações familiares de fato. -3. Motivos e critérios da Rechtsfortbildung - Ctitétio de conexão específica para ressarcimento de danos morais? - IV. O direito internacional dos contratos. -V. O direito transnacional, - VI. Resumo e observações finais.

Nota da Revisora: Este artigo clássico de Erik Jayme de 1986, merece publicação em 2003 no Brasil e em sua forma original, apesar das inúmeras modificações no direito material e direito internacional privado na Alemanha de 1986 a 2003, justamente porque examina a força de adaptação da jurisprudência, quando a lei materiàl evolui ou muda, como com a entrada em vigor do novo Código Civil Brasileiro em 2003, sem que a norma de conflitos de leis no espaço seja modificada, como ocorre com a manutenção da Lei de Introdução ao Código Civil de 1942.

* Tradução livre dos integrantes do Grupo de Pesquisa CNPq/UFRGS, Ana Gerdau de Borja, Luciana Quinto, Maitê de Souza Schmitz, Marilia Zanchet, Rafael Pellegrini Ribeiro, Ricardo Castro e Tâmara Joana Biolo Soares e revisão atualizadora da Profa. Dra. Claudia Lima Marques (UFRGS). Texto publicado in Contratto e impresa, vol. IV (1988), n. 2, p. 423-458, com o título "Formazione progressiva del diritto internazionale privato da parte dei giudici: l'ésperienza americana e tedesca." Para a sua publicação no Brasil, a parte $V$ do texto original, referente ao Direito internacional privado europeu foi retirada, tendo em vista a extensção do texto e uma vez que a base legislativa usada neste texto de 1986 do direito comunitário europeu sofreu profundas modificações. 


\section{I - Introdução**:}

1 - A Rechtsfortbildung, isto é, a produção de direito, pressupõe um direito passível de ser produzido. Aquj, a princípio, contempla-se um direito escrito, cujas lacunas vêm sendo preenchidas pela sentença do juiz. ${ }^{1}$ Por outro lado, a atual codificação do direito internacional privado, contida na EGBGB-1896, Lei de introdução ao Código Civil alemão, descuida quase completamente de áreas jurídicas inteiras, tais como o direito dos contratos e os direitos reais. ${ }^{2}$ Mas também aqui poderá se falar em Rechtsfortbildung somente à medida que as decisões dos juízes abandonem certos princípios já consolidados e os substituam por novos.

A questão da produção judicial resguarda, portanto, seja as normas de conflito codificada, seja as normas sobre conflitos de leis, consolidadas no direito consuetudinátio através da aplicação por parte dos tribunais. ${ }^{3}$

2 - No âmbito das notmas de conflito, surgem novos problemas, no momento em que a reforma de normas materiais guarda consigo a questão se essas normas materiais encontram aplicação também em casos que apresentarn momentos de conexão com um direito estrangeiro. No direito alemão - diferentemente de muitos outros direitos estrangeiros ${ }^{4}$

** Esta contribuição foi escrita em virtude de um período passado na Universidade de Berkeley da Califórnia. Agradeço o bibliotecário de direito internacional, Sr. Thomas Reynolds, pos sua permanente ajuda. Muitos estímulos e indicações devo aos meus interlocutores nesse período, Hanns Hohmann e Chibli Mallat, como também ao meu assistente, Valentin Boll.

Observação - 1988. Este artigo aparece, em 1986, na Festschrift no âmbito de jurispnudência do $600^{\circ}$ aniversário da Universidade de Heidelberg (C.F. Muller-Verlag). Em razão do pronuncianento da corte constitucional, que havia declarado a inconscitucionalidade de algumas normas do EGBGB, como também do $\$ 606$ b do $Z \mathrm{PO}$, o Bundestag, ao final, reformou o direito incernacional privado. A reforma da lei entrou em vigor em $1^{\circ}$ de setembro de 1986 . A nova lei, contudo, constirui apenas modificação parcial (V. Jayme, Il nuovo diritto internazionale tedesco e ele telazioni commerciali italo-germaniche, in Riv. Dir. civ, 1987, II, p.1). A lei concerne à parte geral do direito internacional privado, às pessoas físicas, ao direito de família e sucessōes. Ademais, a Convenção de Roma de 19 de junho de 1980 sobre a lei aplicável às obtigações contratuais é recebida como lei nacional. Restam, pois, validar outras observaçôes envolvendo outras matérias, sobretudo as obrigações extracontratuais. O legislador acolheu, além disso, muitas soluções elaboradas pela jurisprudência, a exemplo daquelas do âmbito do divórcio. Por fim, restam sempre os problemas de caráter geral que trataram de ser, após, investigados, através de exemplos práticos (v até úlimo JAYME/BISSIAS, Auskunftanspruch und ausländisches Ehegüterrechtsstatut - Zur Fortbildung greichischen Rechts durch deutsche Gerichte, in IPRAX, 1988, p. 94).

1 Ver, p. ex., LARENZ, Richterliche Rechtsfortbildung als methodisches Problem in NJW, 1965, p. 1 ss.

${ }^{2}$ ARNAT in ERMAN, Handkommentar zun Bürgerlichen Geseczbuch, 1982, ao aratigo 7 EGBGB redação 1; MESSEN, Zu den Gtundlagen des internationalen Wirtschaftsrechts, in AöR, 110 (1985), p. 298 ss. O. 405 ss.

${ }^{3}$ Esta contribuição concerne à produção das normas abstratas, seu conflito de lei, veja sobre criação jurídica concreta Wengler, Die Funktion der richterlichen Entscheidung über internationale Rechtsverhältnisse, in RabelsZ. 16 (1950), p. 1 ss. a p. 30 s. Ver pelo testo Juenger, Wandel uns Wandlungen des Internationalen privatrechts, in Holl/Klincke (ed.) Internationales Privatrecht Internationales Wirtchaftsrecht, 1985, p. 91 ss.

4 Ver, por ex., Jayme, in IPRax, 1983, p. 305 ss., com respeito à nova lei italiana de adoção. Um ótimo exemplo é também o Matrimonial and Family proceedings Act 1984 inglês (Family Law 49:3), que 
- o legislador apenas em raros casos guarneceu novas leis com regras de conflito. ${ }^{5}$ Neste sentido, as vánias leis de reforma do direito de familia, que fizeram desta área algo completamente novo, não contêm nenhuma regra de conflito. ${ }^{6} \mathrm{Na}$ abordagem do EGBGB, evidenciam-se contrastes, que levaram ao surgimento de novas regtas a partir da jurisprudência. ${ }^{7}$ Isto é verdade, acima de tudo, no tratamento de filhos havidos fora do casamento. ${ }^{8}$ Ademais, a doutrina discute a Rechtsfortbildung do direito internacional privado, principalmente, no que toca às regras de qualificação, ou seja, ao enquadramento de novas questões jurídicas no sistema já existente. Parece-me que os conceitos gerais do EGBGB são já suficientemente amplos para viabilizar uma interpretação correta também de institutos jurídicos de direito interno, por exemplo, o Versorgungausgleich. ${ }^{10}$ Apenas em casos excepcionais as novas normas materiais conduzem a lacunas no direito internacional privado, que serão, por conseguinte, supridas através da aplicação por analogia de normas existentes, ou mediante a produção de novas regras. ${ }^{11}$ Após, aqui será, portanto, trarada primordialmente a produção das mesmas normas de conflito, e não tanto a sua extensão a novas questões objetivas.

3 - O direito internacional privado apresenta, no âmbito da Rechtsfortbildung, outra particularidade, que depende do modo de solução de uma controvérsia com momentos de conexão com um direito estrangeiro. Isro é, tal solução verificar-se-á em duas fases ${ }^{12}$ : na

regula detalhadamente as conseqüềncias do divórcio depois do fim do matrimônio no exterior. Ver, além disso, a lei Ennlandesa sobre os sobrenomes de agosto de 1985 que no capitulo 6 contém um detalhado regulamento do direito internacional ao nome.

"O exemplo muito importante é a AGB-Gesetz (Lei sobre condiçōes gerais dos contratos) $) 6910 \mathrm{Nr}, 8,12$; Ver também a lei sobre ensino por correspondência de 26 de agosto de 1976 (BGB I, 2525) \$ 11.

6 Ver Jayme, Eherechtsreform und Internationales Privatrecht, in NjW, 1977, 1378 ss.

7 A respeito do Versorgungsausgleich, ver $\mathrm{BGH}, 7$ de novembro de 1979, in BGFZ 75, 241; BGH, 8 de Junho de 1983, in BGHZ 87,359 e JZ 1984, 139, nota Lüderitz; Jayme, Der Versorgungsausgleich im internationalen Privatrecht, in Zacher (ed.) Der Versorgungsgleich im internationalen Vergleich und der zwischenstaatlichen Praxis, 1985, p. 101 ss.; Nolte-Scharting, Der Versorgungsausgleich in Fällen mit Auslandsberührung, 1984

8 Kropholler, Die Kollisionsregeln des BGH für die Festestellung und Anerkennung der Vaterschaft, in NJW, 1976, p. $1011 \mathrm{ss}$.

9 MünchKomm/Sonnenberger, 1983, Einleitung IPR, nn. 300-302; Wengler. Die Qualifikation der matjerellen Rechtssätze im internationalen Privatrecht, in Festschrift Martin Wollf, 1952, p. 337 ss. Referindo-se a um "procedimento de classificação que, por sua natureza, é um procedimento normativo".

10. Ver Jayme, Versorgungsausgleich mit Auslandsberühtung und Theorie des Internationalen Privatrechts, in Zacher, (ed.), op. cit. à nota 7, à p. 424.

${ }^{1:}$ No caso de normas materiais estrangeiras, no passado se preferiria julgar que, na ausência de conformidade com o direito material alemão, essa não seria subordinada às regras de direito internacional privado alemãs (ver Melchior, Die Grundlagen des deutschen internationalen Privatrechts, 1932, p. 118 ss.), e por isso se falava de "lacuna"; ver M. Wolff, Das Internationale Privatrecht Deutschlands3, 1954, p. 57; ver tambén genericamente Magalhães Collą̧o, Da qualificção em direito internacional privado, Lisboa, 1964, p. 184; vex, por ex., Galvão, Rückverweisung in deutsch-portugischen Legitimationsfällen? In IPRax, 1984, p. 257 ss., $258 \mathrm{s.}$

12 A "teotia das duas fases de direito internacional privado", por resolver situações de conflito, pretende, além disto, considerar o direito estrangeiro como fato também na segunda fase. Ver sobre esse tema 
primeira fase, uma regra de conflito fará remissão a normas materiais; após, o caso deverá ser decidido com referência à norma de direito assim individualizada. Em cada uma dessas fases, a Rechtsfortbildung poderá ocupar seu papel específico.

A título de exemplificação, citause uma sentença do Amstgericht de Charlottenburg, de 13 de janeito de $1981^{13}$ : trarava-se de controvérsia relativa a alimentos entre cônjuges turcos separados que viviam em Berlim. ${ }^{14}$ A mulher pleiteava uma antecipação das custas judiciais, não prevista expressamente no direito turco, em virtude da aplicação do Art. 14 do EGBGB. O pedido fundava-se no fato de que as custas processuais na Turquia seriam, claramente, muito menores do que na Alemanha. ${ }^{15} \mathrm{O}$ Tribunal pronunciou-se no sentido de que o juiz alemão "poderá desenvolver, ulteriomente, o direito estrangeiro em casos específicos, se desconhecidos pelos tribunais do país", acolhendo a demanda. Tratava-se, pois, da produção de direito turco por parte dos rribunais alemães. ${ }^{16} \mathrm{O}$ Amstgericht Charlottenburg referiu-se, neste caso, também à norma, acolhida no direito turco, do Art. 1, $\S 2$ do ZGB (Código Civil Sứço), segundo a qual se é inviável a extração de norma a partir da lei, o juiz há de decidir consoante o direito consuetudinário e, na falra deste, seguir a regra que adotaria na qualidade de legislador. ${ }^{17}$

Hessler Sachliche Generalklausel und internationales Familienrecht - Zu einer zweistufigen Theorie des internationalen Privatrechts, 1985; Jayme, in Zacher (ed.) op. cit. à nota 7, p. 424 s.; sobre o direito das obrigações ver Stolj, Deliktsstatur und Tatbestandswirkung ausländischen Rechts, in Festschrift Lipstein, 1980, p. 259 ss.; Ractke, Schldstatuí und Eingirffstecht, in ZugIRWiss, 84(1985), p. 325 ss., a p. 341 ss.

13 IPRax 1983, 128; ver sobre esse tema Rumpf, Zur "Fortbildung" türkischen Unterhaltsrechts durch deutsche Gerchte - Prozesskostenvorschussp Richt unter Türkischenehegatten, in IPRax, 1983, PP, 114-116. ver também ord, AG Kitzingen, 30 de novembro de 1984 - F. 252:84 - ; o pedido de perícia, atıavés do outro, era orientada também no senuido de "se fosse admitida uma sentença em conformidade ao $\$ 1672$ BGB como produção do direito turco".

${ }_{14} \mathrm{Na}$ Turquia era no curso de uma ação de divórcio. Esta duplicação dos juízos era de reputar-se ao fato de que a Turquia, no passado, afirmava exclusivamente a jurisdição do tribunal turco pelo divórcio de cônjuge turco, independentemente se vivia na Turquia ou no exterior. Este fato, por sua vez, teve como conseqüência que os tribunais alemães eram privados de competência internacional, faltando o reconhecimento da sentença alemã de divórcio na Turquia (ver $\$ 606$ b ZPO). Em seguida à reforma de direito internacional privado e processual na Turquia (1982) uma tal competência exclusiva nâo subsistiu mais. Ver Krüget, Das türkische IPR-Gesetz von 1982, in IPRax, 1982, p. 252 ss.; Ansay, Zur Scheidung von Türken in der Bundestepublik Deutschland nach Inkrafttreten des neuen IPR-Gesetzes, in StAZ, 1983, p. 29 s.; Krüger, Anerkennung deutscher Scheidung türkischer Eheleute, in MPRax, 1985, p. $370 \mathrm{~s}$.

is Ver RUMPF, op. cit. à nota 13, p. $114 \mathrm{~N}^{0} 13$.

16 De forma similiar, OLG Oldenburg, 23.06.1981, in FamRZ, 1981, p. 1176 s., com devolução ao Rechtsfortbildung do direito suíço.

17 Para um caso de aplicação do artigo 1 do ZGB suiço na jurisprudência italiana, ver Trib. Torino, 27 de Jutho de 1948, in Giur. It., 1949, 1, 2, c. 273. Ver sobre esse tema, CANSACCHI, Qualificazione e richiamo della legge straniera, in Giur. It., 1949, 1,2, c. 273 55., a cc. 277-278; JAYME, Die italienische Rechtsprechung zum internationalen Privat- und Prozej3recht 1945-1966, in RabelsZ, 31 (1967),446 ss. 464. Sobre a importância do artigo 1 ZGB para os casos estrangeiros, ver, além disso, VISCHER, Dex Richter ats Gesetzgeber im intemaxionalen Privatrecht, in Schweizerisches Jahrbucb für Internationales Recht, volume XII, 1955, pp. 75 ss., 82 s., assim como a jurisprudência suíça mais recente, Zivilgericht BaselStadt, 17 de Julho de 1981, in ZZW 53 (1985), Pp. 37455.376 (mudança de sexo de uma senhora francesa). 
Esses e demais problemas similares surgem, continuamente, quando da aplicação do direito estrangeiro, visto que o juiz alemão muitas vezes se confronta com um caso particular, não proposto aos tribunais daquele país em que o direito deveria ser aplicado. Surgiria um outro problema se, por exemplo, fosse lícito ao juiz valorar o direito estrangeiro na medida da Constituição estrangeira; nesse caso, deveria ser respeitada a competência absoluta da Corte Constitucional estrangeira. ${ }^{18}$

Há juristas que rejeitam em geral a Fortbildung criativa do direito estrangeiro por patte do juiz inrerno. ${ }^{19}$ Todavia, observa-se justamente que o reenvio envolve também aquelas normas estrangeiras que aurorizam o juiz à Rechtsfortbildung. ${ }^{20}$

4 -Um problema central na produção judicial do direito é tepresentada, contudo, no questionamento se e como o juiz interno poderia elaborar as próprias regras de conflito. Aqui, apresenta-se um problema particular: na teoria mais recente do direito inremacional privado há posicionamentos que convidam o juiz a prescindir da produção abstrata de normas e a determinar a "norma do caso" ${ }^{21}$ significativa, com ajuda de método embasado no conflito de normas materiais do caso concreto. ${ }^{22}$ É difícil, a meu ver, definir tal criação caso a caso do direito como Rechtsfortbildung.

Sobre o assunto, cito o caso Frummer v. Hilton Hotels International Inc., da jurisprudência do estado de Nova Iorque $e^{23}$ : um nova-iorquino visitou Londres, hospedando-

${ }^{18}$ Ver a esse respeito, BayObLG, 21 de fevereiro de 1969, in FamRZ, 1969, 341 ss., 343 (não há remessa á corte constitucional italiana por parte de um tribunal alemão). Ver, genericamente, a esse tespeito, KUNZ, Das richterliche Prüfungsrecht im intenationalen Staatsrecht, in NiemeyersZ 32 (1924), p. 26 ss.

19 NEUMAYER, Fremdes Recht und Normenkontrolle, in RabelsZ, 23 (1958), pp. 573 55., 592-593.

${ }^{20}$ Assim, CAN5ACCHI, op. cito à nota 17, c. 278. ver, também, em contexto análogo, DE NOVA, Legge 5traniera e controllo di costituzionalità, in Foro pad., 1955, IV, C. 1 5S. ac. 5-7; VON HOFFMANN, «Lex mercatoriay vor internationalen Schiedsgerichten, in IPRax, 1984, p. 106 sS. ap. 107-108. Entretanto, são superficiais e limitados sobre a questão da determinação do cireito substitutivo frente à impossibilidade de estabelecer o conteúdo do direito estrangeiro. Ver a esse respeito, WENGLER, Der deutsche Richter vor unaufklärbarem und unbestimmtem ausiändischen Recht in JR. 1983, p. 221 5S., a p. 225.

${ }^{21}$ Sobre a teoria da "norma do caso", ver. FIKENTSCHER, Methoden des Rechts, vol. IV, 1977, p. 202 ss.

${ }^{22}$ Ver, por exemplo, Brainerd CURRIE, Survival of Actions: Adjudication versus Auto-mation in the Conflict of Laws, in Stanford L. Rev, 10 (1958), p. 205 55. a p. 218 55.; SEDLER, The Governmental Interest $\Lambda$ pproach to Choice of Law: An Analysis and a Reformulation, in UCLA L. Rev, 25 (1977), p. 181 5S., a p. 208. O caso mais famoso por este método é Babcock v. Jackson, 191, N.E. 2d 279 (Ct. App. N.Y. 1963). Ver também, porém, REESE, Choice of Law: Rules or Approach, in Cornell L. Rev., 57 (1971-72), p. 315 ss.; JUENGER, Möglichkeiten einet Neuotientierung des internationalen Privatrechts, in NJW, 1973, p. 1521 ss., a p. 1524. Obter a solução da norma nos conflitos de leis da interpretação da norma material, como atividade de "criação do direito" por parte do jủz (EHRENZWEIG, Festschrilt Wengler, Vol. 2, 1973, p. 251 55., a p. 259); no caso normal, porém, não se ttata de Rechtsfortbildung.

${ }^{23}$ Frummer v. Hilton Hotels International, Inc., 304 N. Y.S., 2d 335 (Sup. Ct. 1969): ver sobre esse tema, JAYME, Zur Krise des "Govemmental-Interest Approach », in Festschrilt Kegel, 1977, p. 359 ss., a p. 363-364. Anteriormente a questão da competência internacional do juiz de Nova lorque era estado decisivo em sentido positivo: Frummer v. Filton Hotels International, Inc:, 281 N. Y.S. $2 d 41$ (Ct. App. 1967). De modo análogo ao juiz de Nova Jorque decide a Supreme Court of Mississippi no caso Mitchell v. Crait, 211 So. 2d 509, 514 (Miss. 1968); ver sobre esse tema, CAVERS, The Value 01 Principled Prelerences, in Texas L. Rev. 49 (1971) 211,214-215. 
se no Hotel Hilton. Enquanto se preparava para tomar banho, caiu na banheira, descrita na Court of Appeals de Nova Iorque como uma "modernistic type bathtub". 24 Alegou ter sofrido graves lesões, demandando uma indenização de 150.000 dólares. A Ré excepcionou, entre outros, a con-culpa do Autor que, segundo as leis de Nova Iorque, teria afastado completamente o direito à indenização. ${ }^{25} \mathrm{O}$ direito inglês, por outro lado, previa uma repartição do dano a partir da "comparative negligence rule". Seguindo-se o método aplicado no estado de Nova Iorque, o tribunal examinou, em preliminar, a finalidade das respectivas normas materiais e, num segundo momento, o interesse dos países considerados no atinente à aplicação das regras de conflito: ao firm, aplicou o princípio da "better law", decidindo que o direito inglês era o melhor. A norma de Nova Iorque já era superada e por demais restritiva nos casos de dano. ${ }^{26}$

Uma escolha assim entre dois direitos possíveis, que implica a criação de direito, não é de todo estranha nem mesmo ao Dircito Internacional Privado alemão. O Amtsgericht Ebersberg, por exemplo, teve de enfrentar a questão se um marido egípcio devia responder pelas dívidas de sua esposa. ${ }^{27}$ Segundo o art. 16 do EGBGB isso dependia da análise se, em relação ao terceiro, o direito alemão (no caso o $\$ 1357$ do BGB) seria "mais favorável" que o direito egípcio aplicável.

Me parece, porém, que não se trata aqui de Rechtsfortbildung, porque certas regras podem ser extraídas gradualmente também através de repetidas conctetizações ${ }^{28}$.

5 - Nos métodos do direito americano predominantes na década de 80, exprime-se uma divergência em relação ao diteito internacional privado clássico. Desejava-se assim dar maior destaque aos objetivos das normas materiais, e também impedit o emprego de conceitos abrangentes demais nas regras de conflito, para todos os problemas em questão. Pot isso, foi desenvolvida uma séric de instrumentos para melhor satisfazer as exigências do caso particular, instrumentos introduzidos também na Europa. Menciona-se, como exemplo, o "dépeçage", ou seja, a aplicação de diversos direitos a questões diversas oriundas da mesma situação de fato ${ }^{29}$.

${ }^{24}$ Frummer v. Hilton Hotels International, Inc., 281 N. Y.S. 2d, 41, 42 (Ct. App. 1967).

${ }^{25}$ Relativo à "contributory negligence» ver PROSSER \& KEETON, On the Law of Torts, 1984, p. 451 ss., a p. 468 ("The doctrine appears...to be a dying one...").

${ }^{26} \mathrm{O}$ «better-law approach» de Leflar. Ver. LEFLAR, Choice-Influencing Considerations in conflicts Lau, in N.Y.U.L. Rev. 41(1966) 267ss.

27 Ver JAYME, Rechtsvergleichung im internationalen Privatrecht, in Festschrift Schwind, 1978, p. 103.

${ }^{28}$ Ver a esse respeito a teoria dos conflitos de lei de David Cavers baseada sobre "principles of preference": CAVIRS, The Choice-of-Law Process, 1965, e, a esse respeito EHRENZWEIG, A Counter-Revolution in Conflicts Law? From BEALE to CAVERS, in Harvard L, Rev., 80 (1966), pp. 377 ss., 387, 390 ss.; CAVERS, The Choice of Law-Selected Essays, 1933-1983, Duke University Press, Durham, 1985, p. 149 ss.; 0 mesmo CAVERS, op. cit. na nota 23, pp. 211, 215, rejeita, todavia, o critéxio da "better law" como "principle of preference". Para de importa a "conflicts justice": ver CAVERS, Cipolia and Conflicts Juscice, in Duquesne L. Rev. 9 (1971), p. 360 ss., isto é, ele relaciona os objetivos das normas materiais às particularidades do caso concreto de conflito de leis e rejeita uma apreciação de comparação abstrata.

27. Ver a esse respeito WILDE, Dépeçage in the Choice of Tott Law, in Southern California Law Review, 41 (1968), p. 329 ss.; REESE, Dépeçage: A Common Phenomenon in Choice of Law, in Columbia L. 
$\mathrm{Na}$ Rechtsfortbildung, uma figura jutídica assume um significado particular, qual seja a chamada "cláusula de exceção" ${ }^{30}$. Aqui se trata da situação em que o juiz de um caso particular pode decidir segundo a eqüidade; ou seja, é confetida a ele a possibilidade de enunciar uma nova tegxa diferente daquela codificada. Hoje, a pátria da notma de exceção éa Sứça ${ }^{31}$. Mas também o projeto de lei alemão de 1983 para a revisão do direito internacional privado contém cláusulas de exceção que provêm dos Tratados de Roma da CEE sobre o direito aplicável às relações obrigacionais derivadas do contrato (1980). No art. 28 do EGBGB, segundo o rexto do projeto de 1983, são previstos para os contratos (na falta de escolla da parte) certos critérios objetivos de conexão $0^{32}$. Afirma-se, então, no $₫ 5^{\circ}$ da mesma norma: "As previsões dos $₫ \llbracket 2^{\circ}, 3^{\circ}$ e $4^{\circ}$ não valem quando, da totalidade das circunstâncias, resulta que o contrato tenha conexões mais estreitas com um outro Estado". Uma regra semelhante existe para os contratos de trabalho no art. $30, \$ 2^{\circ}$, última parre, EGBGB, do projeto de reforma ${ }^{33}$.

Essas cláusulas de exceção, em tese, estão se tornando possíveis na prática face a necessidade de lidar melhor com a multiplicidade dos estados internacionais de fato ${ }^{34}$. Deveria ser, porém, o caso particular, a meu ver, o ponto de partida para a criação de uma nova regra. A cláusula de exceção é vista desse mesmo modo também na doutrina suíça, a qual reafirma que o juiz deve criar uma regra modo legislatoris, a qual devetá ser aplicável também nos casos

Rev. 73 (1973), p. 58 ss.; LAGARDE, Le "dépeçage" dans le droit international privé des contrats, in Riv. dir. int. priv. e proc,, 1975, p. 649 ss.; LAGARDE, The European Convention on the Law Applicable to Contractual Obligations: An Apologia, in Virginia Journal of International Law, 22 (1981), p. 91 ss., 96.

30. Ver a esse respeito SCHURYG, Kollisionsnorm und Sachrecht, 1981, p. 338 ss.; DUBLER, Les clauses d'exception en droit international privé, Genebra, 1983; NADELMANN, Choice of law Resolved by Rules or Presumptions with an Escape Clause, in Am. Joum. Comp. Law, 33 (1985), p. 297 ss.; CAMPIGIJIO, L'esperienza svizzera in tema di clausola d'eccezione: l'art. 14 del progetto di riforma del diritto internazionale privato, in Riv. dir. int. priv. proc., 1985, p. 47 ss.

31 VISCHER, Drafting National Legislation on Conflict of Laws: The Swiss Experience, in Law \& Contemporary Problems 41, N. 2 (1977), p. 131 ss.; BUCHER, Auslegungsregeln in der neueren Gesetzgebung des schweizerischen internationalen Privatrechts, in Festschrift Meier-Hayoz, 1982, p. 45 ss.; KNOEPFLER, Utilité et dangers d'une clause d'exception en droit isternational privé, in Hommage à Raymond Jeanprêtre, Neuchâtel, 1982, p. 113 ss. Un estudo/investigą̧ăo/pesquisa/ exame sobre o tema está em VON OVERBECK, Les questions générales du droit international privé à la lumière des codifications et projets récents, in Recuell des Cours, 176 (1982-III), p. 9 ss., p. 186 ss.

${ }^{32}$ Entwurf eines Gesetzes zur Neuregelung des Internationalen Privatrechts, in BT-Drucksache, 10/504 (20/10/1983); p. 12.

3. Ver a esse respeito GAMILISCHEG, Ein Gesetz über das Internationale Arbeitsrecht, in Zeitschrift für Arbeitsrecht, 1983 , p. 307 ss., a p. 307 ss., a p. 330 ("decisão sábia"); KRONKE, Das Arbeitsrecht im Gesetzentwurf zur Neuregelung des Internationalen Privatrechts, in DB, 1984, p. 404 ss., a p. 405 ("em cada caso necessário").

${ }^{34}$ Segundo KREUZER, Berichtigungsklauseln im Internationalen Privatrecht, in Festschrift Zajtay, 1982, p. 295 ss., a p. 315, trata-se aqui de "impor a idéia de eqüidade no sentido da justiça do caso concreto". Na minha opinião a cláusula de exceção deveria tomat possível uma produção mais fina da regra. Concebendo-a mais no sentido da justiça do caso concreto corre-se o risco de que a aplicação da norma geral sobre os conflitos de lei deve ser sempre legitimada. Por isso deveria-se deixar a "correção" no caso concreto às notmas materiais aplicáveis: assim exatamente BHG, 26 de maio de 1982, in IPRax, 1983, 180 ss., a p. 184 para $\$ 1587$ c do BGB. 
posteriores similares ${ }^{35}$. A cláusula de exceção se torna, assim, o instrumento de uma Rechtsfortbildung institucionalizada. No que tange ao direito alemão, contudo, não há ainda uma experiência em que foi aplicada a cláusula de exceção ${ }^{36}$.

6-Antes de nos determos sobre questões particulares, é necessário enfrentar, ainda, o problema dos critérios da produção judicial no direito internacional privado ${ }^{37}$.

Parece exemplar aqui uma sentença do Reichsgericht ${ }^{38}$; tratava-se do divórcio de um casal de cônjuges islandeses. A autora era, originalmente, de nacionalidade alemã, mas adquirira, com o casamento, a nacionalidade islandesa do marido, perdendo a alemã. $O$ seu pedido tinha sido informado ao marido em 03 de setembro; em 07 de outubro o marido denunciou ao cartório do Município de sua residência a sua mudança de domicílio dentro da Islândia ${ }^{39}$.

Segundo 0 art. $17 \$ 1^{\circ}$ do BGB, era aplicável o direito islandês. Nas causas matrimoniais e familiares, porém, a Islândia segue o princípio da residência ${ }^{40}$. Portanto, fazia um reenvio ao direito alemão (art. 27 EGBGB), Ao contrário, permanecia incerto o momento julgado decisivo da norma islandesa sobre os conflitos de lei. O Reichsgericht pronunciou-se a favor do reenvio: poderiam ser originadas desvantagens "caso se ligasse a uma mudança de residência do demandado, verificada apenas após a proposição da demanda, a conseqüência de provocar a mudança da disciplina legai do divórcio aplicável no início da ação. O tequerido teria o poder de negar à parte autora o direito ao divórcio". O Reichsgericht assim prosseguiu41:

"Nenhum elemento faz crer que o direito islandês queira recusar-se a reconhecer essas considerações que emergem da natureza do litígio. $\mathrm{Na}$ falta de disposições explícitas dever-seá admitir que corresponde também à ratio do direito islandês o fato que, inobstante uma mudança de residência do réu verificada no curso da ação, seja mantida aplicável, também após, a mesma disciplina legal do divórcio aplicável no início da ação, mesmo quando, como aqui, o demandado tenha transferido a sua residência na mesma Islândia."

${ }^{33}$ Vischer, op. cit. à nota 31, p. 139; Bucher, op. cit. à nota 31, p. 61; von Overbeck, op. cit. à nota31, p. 205; Jayme, Considérations historiques et actuelles sur la codification du droit international prive, in Recueil des Cours, 177 (1982-IV), p. 9 ss., a p. 84.

${ }^{36}$ Ver, entretanto, também Nadelmann, op. cit., nota 30 considerando á o precedente histórico

${ }^{37}$ Do ponto de vista pelo advento da cláusula de exceção somente data de Vischer, op. cit. à nota 31, p. 139-140, e de Kreuzer, op. cit. à nota 34, p. 322 e 55.

${ }^{38} \mathrm{RG}, 6$ de Abril de 1936, in RGZ, 151, 103.

${ }^{39}$ A corte aceita a perpetio fori no sentido de uma perpetuatio jurisdictionis; ver sobre esse tema, porém, Damrau, Fortdauer der internationalen Zuständigkeit trotz Wegfalls ihrer Voraussetzungen?, in Festschrift Bosch, 1976, p. 103 ss.; relativo à situação da causa cfr. Zöller/Geimer, ZPO14, 1984, in IZPR, P. 633-634.

40 Eyjóltsson, Das Eherecht Islands, in Leske/Locwenfeld, Rechtswerfolgung im internationalen Verkeht, vol. IV, 1937, p. 750 ss, a p. 761; Löning, Die Ehescheidung von isländern vor deutschen gerinchten, in Zeitschrift für ausländisches und internationales Privatrecht, 9 (1935), p. 405 ss., a p. 410; ver, além disso, Bergmann/Ferid, Internationales Ehe-und Kindschaftstecht, Island, p. 4 ss.

${ }^{41}$ Cit. supra, nota 38, p. 109. O BGB, 26 de maio de 1982, in IPRax 1983, 180 ss., a p. 184, toma em consideração a mudança de nacionalidade durante a ação de divótcio no âmbito da norma material; ver sobre esse tema, Jayme, op. cit, à nota 7, p. 424s. Relarivo ao "Rechtsfortbidlung" na base a natura della cosa, ver genericamente Larenz, op. cit. A nota 1, p. 5-7. 
Percebe-se que o Reichsgericht tentava introduzir uma regra válida no âmbito internacional para a mudança de disciplina legal. A produção do direito estrangeiro sobre os conflitos de leis e o desenvolvimento dos princípios gerais da natureza do litígio convergem, especialmente porque aqui se devia decidir sobre a aplicabilidade de nomas materiais alemãs. A possibilidade de internacionalização da nova regra torna-se um critério fundamental que guia, ou pelo menos deveria guiar, a Rechtsfortbildung no direito internacional privado ${ }^{42}$.

\section{II - O princípio da igualdade do Grundgesetz e a Rechtsfortbildung do direito internacional de familia}

O motivo principal para a criação de novas normas sobre conflitos de leis por parte da jurisprudência deveu-se ao fato de que muitas normas do EGBGB não correspondem ao princípio da igualdade (isonomia) consagrado na Constituição (art. $3, \S 2^{\circ}$, Grundgesetz), uma vez que estão ligadas à nacionalidade do marido ou do pai ${ }^{43}$. Enquanto parece fácil declarar a inconstitucionalidade de uma norma, difícil se torna substitui-la por uma nova ${ }^{44}$. Esse terá sido o motivo mais importante pelo qual a prática (apoiada em parre da doutrina) ${ }^{45}$, por um longo periodo, conservava as normas antigas ${ }^{46}$. Isso ocorria ainda que a Corte constitucional federal tivesse declarado, na sentença dos espanhóis (Spanienfall) de 04 de maio de 1971, o princípio segundo o qual as normas de direito internacional privado alemão devem ser harmonizadas com os direitos fundamentais ${ }^{47}$.

Havia, contudo, também algumas sentenças de juízes que, de forma cautelosa, ousaram praticar uma Rechtsfortbildung, especialmente para o regime jurídico dos efeiros pessoais do casamento e a aquisição do sobrenome do marido por parte da esposa $a^{48}$. A

42 Ver sobre esse tema a "opinião dissidente" do Juiz Breitel in Frummer v. Hilton Hotels International, Inc., 281 N.Y.S. 2d, 41, 46 ss., 51-52 (Ct. App. N.Y. 1967); ver também BGH, 8 janeiro de 1985, in VJZI 1985, 441, 442 "Deve, entretanto, haver também o correspondente desenvolvimento das notmas de conflito de leis de outros ordenamentos juridicos (a esse respeito Hohloch, JuS. 1980, 18, $19 \mathrm{~s}$ ) e o dever de harmonização assim codificado"; BGH, 8 de março de 1983, in BGHZ 87,95,100, e ver sobre esse tema, Weick, Das Tatortprinzip und seine Binschränkung bei internationalen Verksunfällen, in NJW, 1984, 1993 ss., $1994 \mathrm{~s}$.

${ }^{43}$ Ver sobre o tema Sturm, Durchbruch der Grundrecht in Fällen mit Auslandsberührung, in Fam R, 1972, p. 16 s5.

${ }^{44}$ Cfr. Henrich, Art. 15 EGBGB nichtig: Was nun?, in IPRax, 1983, p. 208 ss.

${ }^{45}$ Ver a prova in Sturm, Zux Gleichberechtigung im deutschen internationalen Privatrecht, in Festschrift Heidelbetg, 1967, p. 155 ss., 157, No 8.

46 Ver, por exemplo, BGH, 9 de julho de 1980, in IPRax, 1981, 23 ds.; ver sobre esse tema, Otto, Gïterrecht und IPR, in IPRax, 1981, p. 11 ss.

47 BverfG, 4 de majo de 1971, in BverfGE 31, 58; ver sobre esse tema Müller-Freienfels, "Spanierheiraten" Geschiedener im Meinungsstreit, in Festschrift Kegel, 1977, p. 55 ss.

48 Ver STURM. Der Name der Ehefrau aus kollisionsrechtlicher Sicht, in FamRZ, 1972. p. 394 ss;; HENRICH. Alternativen zur Anknüpfung an den gewöhnli- chen Aufenthalt in gemischt-na/ionalen Ehen, in IPRax. 1983. p. 62 ss. 
verdadeira e própria abertura ocorreu apenas quando as propostas de reforma concentraramse em projetos de lei nos quais se podia modelar a introdução de novas normas ${ }^{49}$.

Esse processo de reforma está ainda em andamento (pata citar Beitzke) ${ }^{50}$ e trouxe uma gradual desconstrução do direito internacional de família ${ }^{53}$.

1. O exemplo mais significativo de uma Rechtsfortbildung que teve um bom fim é o divórcio nos casamentos de nacionalidade mista. Na base do art. 17 do EGBGB está o princípio da nacionalidade. Para o divórcio, vigorava o direito nacional do marido no momento da demanda judicial (art. $17, \S 1^{\circ}$ do EGBGB) $)^{52}$. Entretanto, as mulheres alemãs podiam sempre obter o divórcio segundo o direito alemão ex vi art. $17, \llbracket 3^{\circ}$ do EGBGB. À jurisprudência aptesentava-se a questão de como formar o direito internacional do divórcio com referência ao princípio da igualdade da Constituição, quando os cônjuges possuíssem nacionalidades diversas.

A sentença do Bundesgerichtshof de 08 de dezembro de 1982 tratava do divórcio de um austríaco com uma americana, a qual, até 1969 , possuía um passaporte austríaco ${ }^{53}$. A Corte de Apelação federal estabeleceu que o art. $17, \$ 1^{\circ}$ do EGBGB contrariava o art. $3, \$ 2^{\circ}$ GG, e, quanto ao direito aplicável, fez referência à nacionalidade do marido no caso do casamento misto entre cidadãos de nacionalidade diversas. A corte, portanto, estabeleceu a norma de que o divórcio e as suas conseqüências setão determinados segundo o direito do estado no qual ambos cônjuges tenham tido suas últimas nacionalidades durante o casamento, sendo que ao menos um dentre os dois deve continuar a possuí-la. Assim, era aplicável o direito austríaco. O recurso constitucional da esposa, a qual, evidentemente, tentava obter um Versorgungsausgleich (Compensação de aqüestos) segundo o direito alemão $0^{54}$, não foi acolhido na corte constitucional.

49 Ver infra notas 58, 80. Ver em contexto similar, BAR, Exklusivnonnen und Ausländer unter deutschem Personalstatut. in IPRax. 1985. p. 272 s., que se opõe a uma conexão fundada na sua residência pelo motivo "isso parece sem necessidade e em desarmonia com a tendência do futuro diteito internacional privado relativo ao Versorgungsausgleich alemão".

50 BEITZKE. Sukzessive Demontage familienrechtlichen Kollisionsrechts, in IPRax. 1985. p. 268 ss.

st Ver sobre esse tema HELDRICH, Reform des intematiollolen Familienrechts durch Richterspruch, in FamRZ, 1983, p. 1079 ss.; ver BAR, Das in/emationale Eherecht auf dem Prüfstand der Verfassung, in NJW, 1983. p. 1929 ss.; JAYME, Privtre International Law in Matters of Divorce in Recent German Case Law, in Current Trends of Conflicts of Laws in Central Eastern Europe. Trieste. 1985, p. 45 ss.; BVerfG, 3 de dezembro de 1985, in NJW, 1986, 658, nota GEMER ( 6006 b ZPO).

52 A Corte Constitucional Federal, 8 de janeiro de 1985. in JZ, 1985. 382; in IPRax, 1985, 290 s., declarou inconstitucional o artigo 17. $\$ 1$ EGBGB.

${ }^{53} \mathrm{BGH}, 8$ dicembre 1982, in BGHZ, 86.57; in IPRax, 1983. 236 ss.; ver sobre esse tema JAYME. Zur Neubestimmung des Scheidungsstatuls für gemischtnationale Ausländerehen. in IPRax. 1983, p. 221 ss.

${ }^{54}$ BVerfG, 23 de junho de 1983, in FamRZ. 1983, 1211; in IPRax. 1984.207; ver sobre esse tema HENRICH. Die Scheidung gemischtnationaler Ausländereheo. in IPRax. 1984,186. 
$\mathrm{Na}$ doutrina, houve uma quantidade de propostas sobre a norma que deveria ter substituido $o$ art. $17, \uparrow 1^{\circ}$ do EGBGB, inconstitucional ${ }^{55}$. A Corte Federal referia-se ao "resíduo conforme a constituição" da norma, isto é, ao princípio da nacionalidade ${ }^{36}$. Do art. 17 do EGBGB foi possível destacar, outrossim, o princípio de que "o critério de conexão baseado na nacionalidade não deve pertencer completamente ao passado, mas o seu efeito deverá continuar no presente para pelo menos um dos cônjuges" ${ }^{257}$. A nova regra referente à última nacionalidade comum, corresponde, além disso, às propostas de reforma já registradas ${ }^{58}$ naquele período.

A sentença mostra claramente os fatores que se tornaram decisivos para a produção do direito inrernacional privado. Na maior parte, são os elementos estruturais das regras de conflito em vigor - aqui, o princípio da nacionalidade - que encontram aplicação concreta com a antecipação de futuras soluções legislativas, já presentes como propostas de reforma. Isso apresenta a vantagem de, nas longas fases de transição em que a antiga codificação é abalada, conservar uma certa continuidade, enquanto a nova codificação não entra ainda em vigor.

Embora convincente in abstracto, a solução da suprema Corte Federal se apresenta problemática no contexto dos fatos decididos. Na verdade, a aurora tinha duas nacionalidades durante o casamento, a austríaca e a americana, portanto, era binacional. A Corte levou em consideração apenas a nacionalidade austríaca para decidir se os cônjuges tinham uma nacionalidade comum durante o casamento, afirmando:

"A questão, se nesse contexto, referente a pessoas com dupla nacionalidade, leva em consideração a nacionalidade efetiva, pode ficar aberta (...), porque a nacionalidade austríaca da mulher, embora mantendo sua nacionalidade americana, não era privada de efeitos. No seu caso, aprestava relações com a Áustria não apenas através do marido, mas também diretamente. Ainda depois da separação do casal, construiu uma casa na Áustria e lá viveu temporariamente, além de utilizar o passaporte austríaco até 1969."59

Segundo os principios gerais, o Bundesgerichtshof deveria ter verdadeiramente examinado quais das duas nacionalidades era a prevalente ${ }^{60}$. Enrretanto, na verdade existe $o$ risco de impor-se novamente a nacionalidade do marido - como demonstram outras sentenças ${ }^{61}$.

55 Veja JAYME, op. cit. à nota 6. p. 379. N. 13; OLG Müchen, 17 de dezembro de 1979. in IPRax. 1981. 22.

${ }^{56}$ BGH. 8 de dezembro de 1982, in BGHZ, 86. 57.

57 Nota prec., à p. 67.

58 Alusão in BGH, 8 de dezembro de 1982, in BGHZ. 86, $57,65$.

59. Ivi, p. 69.

${ }^{60}$ Ver o BGH, 20 de junho de 1979, in BGHZ, 75, 32, 39, com provas.

61 Ver no contexto do estatuto dos bens matrimoniais LG Kempten, 3 de abril de 1984, in MPRax, 1985, 167; REINHART, Zum Güterstand gemischt-nationaler Ehen, in BWNotZ, 1985, 97 ss., $98 \mathrm{~s}$. 
Na seguinte sentença de 11 de janeito de 1984, a Corte Federal não podia mais manter o princípio da nacionalidade ${ }^{62}$. Tratava-se da dissolução de um matrimônio no qual a esposa era cidadã da União Soviética, e o marido, de Angola ${ }^{63}$. A esposa vivia na Alemanha, e o marido tinha retornado à sua pátria. Os cônjuges, portanto, não tinham nem uma nacionalidade comum, nem uma vivência habitual comum. A Corte Federal estabeleceu o seguinte princípio:

'O divórcio e as conseqüências do divórcio determinam-se, até o momento em que não é possivel determinar uma nacionalidade comum dos cônjuges, segundo o direito daquele Estado, no qual ambos os cônjuges tenham tido domicilio habitual ou no qual ambos tenham tido o seu último domicilio durante o matrimônio, se um dos dois continua a ter lá a sua própria residência."

Tal regra levou à conseqüência de que um matrimônio celebrado na Rússia entre uma cidadã russa e um cidadão angolano, o qual, ao momento do divórcio vivia em Angola, tivesse sido desfeito segundo o direito alemão, porque a última residência do casal tinha sido na Alemanha, onde a mulher continuava ainda a viver.

Esta passagem do princípio da nacionalidade àquele do domicílio habitual, para o divórcio nos casamentos com nacionalidade mista, representa uma das produções judiciais mais importantes do direito internacional privado. Resta aberta, entretanto, a questão se as regras desenvolvidas para os casamentos de estrangeiros com nacionalidade mista também valeria para quando um dos cônjuges possuísse nacionalidade alema $\tilde{a}^{64}$. O Bundesgerichtshof desenvolveu a regra especial da combinação do disposto nos $₫ \int 1^{\circ} \mathrm{e} 3^{\circ}$ do art. 17 do EGBGB, segundo o qual, no caso de casamento com nacionalidade mista, em que um dos cônjuges é alemão, o pedido de divórcio de cada cônjuge é da jurisdição nacional desse cônjuge $e^{65}$. Pelas conseqüências do divórcio, deverá ser aplicado, em cada caso, o dircito alemão $0^{66}$. O regime do divórcio para casamentos com nacionalidade mista é portanto diferente, caso os dois cônjuges sejam alemães, ou caso um dos cônjuges seja cidadão alemão; porque, neste último caso, o direito alemão é aplicado, sem atenção, à residência habitual comum dos cônjuges ${ }^{67}$.

A Corte Constitucional Federal declarou inconstitucional o art. 17, $\$ 1^{\circ}$ do EGBGB, na sentença de 8 de janeiro de $1985^{68}$. Por isso, questiona-se a possibilidade de ser mantida a

62 BGH 11 de janeiro de 1984, in BGHZ, 89, 325; in IPrax, 1984, 208.

${ }^{63}$ Ver também as decisões das instâncias precedentes: AG Wenningsen/Deister, 14 de outubro de 1981, in IPRspr., 1981, n. 102; OLG Celle, 7 de abril de 1982, in FamRZ, 1982, 813.

${ }_{64}$ Ver a este respeito RAUSCHER, Nichts Neues zu Art. 17 EGBGB, in JZ, 1985, 518 ss.; WINIKLER VON MOHRENFELS, Die Ankuüpfung des Scheidungsstatuts nach Nichtigetklärung des Art. 17 I EGBGB, in NJW, 1985, p. 1264 ss.

${ }_{65} \mathrm{BGH}, 8$ de junho de 1983, in BGHZ 87, 359; in IPRax, 1983, 239. Ver HENRICH, Probleme bei der Scheidung einer gerrischt-nationalen Ehe, wenn ein Ehegatte Deutscher ist, in IPRax, 1983, p. 161 ss.

${ }_{66} \mathrm{BGH}, \mathrm{B}$ de junho de 1983 , cit. nota prec; Ver a este respeito JAYME, cit. à nota 53, p. $222 \mathrm{~s}$.

${ }^{67}$ Ver AG Kelhein, 2 de fevereiro de 1984, in Ipraz, 1985, 109.

${ }^{6} 8$ BverfG, 8 de janeiro de 1985, in $\mathrm{JZ}, 1985,382$; in IPRax, 1985, 290 s., Ver a este respeito BEITZKE, cit. à nota 50; RAUSCHER, cit. À nota 64; WINKLER VON MOHRENFELS, cit. à nota 64. 
regra especial para os casamentos, com nacionalidade mista, nos quais um dos cônjuges é alemão. A única base para tal regra é, atualmente, o art. $17, \$ 3^{\circ}$ do EGBGB, que prevê para o pedido de divórcio da muther alemã a a licabilidade do direito alemão. Essa norma é de ser considerada, porém, inconstitucional, pois a esposa alemã é privilegiada.

Contudo, restou intacto um "resíduo" conforme a Constituição, no sentido de que a cônjuges alemães deveria ser assegurada, possivelmente, a aplicabilidade do direito alemão ${ }^{69}$. Esta idéia poderá ser pouco desejável do ponto de vista internacional; não infringe, porém, o princípio da igualdade de direitos dos cônjuges. Parece-me que poderiam ser conservadas, portanto, as tegras especiais desenvolvidas pelo BGH (Corte Federal Civil), ainda depois da nulidade do art. $17, \Omega 1^{\circ}$ por parte da Corte Constitucional Federal.

2 - Enquanto o direiro internacional do divórcio foi reformulado sobre uma nova base, o direito internacional das relações patrimoniais entre os cônjuges está ainda esperando uma Rechtsfortbildung consolidada.

A Corte Constitucional Federal declarou inconciliável o art. $15, \$ 1^{\circ}$ e $\$ 2^{\circ}$ da primeira parte do EGBGB com o art. $3^{\circ}, \$ 2^{\circ}$ do Grundgesetz, considerando-o, portanto, verfassungswidrig ${ }^{70}$, porque estava ligado à nacionalidade do matido ${ }^{71}$. A questão sobre quais regras devem substituir a norma inconstitucional é controversa ${ }^{72}$. Orientando-se sobre o "residuo" da norma, é necessário, a meu ver, manter a imutabilidade do regime de bens de lege lata ${ }^{73}$. É necessário, dessarte, acertar un regime de bens entre os cônjuges no momento da celebração do casamento. Se os cônjuges, no momento da celebração do casamento, não tinham a nacionalidade comum, é de se considerar a primeira residência hahitual do casal ${ }^{74}$.

A prática, contudo, deve enfrentar o difícil problema de como administrar as repercussões da sentença da Corte Constitucional Federal ${ }^{75}$. Em parte, os tribunais rêm-se

69 BGH, 11 de janeiro de 1984, in BGHZ 89, 325, 335: "A solução divergente para o matrimônio no qual um cônjuge é alemão, faz referência à estrutura da disciplina especial que contem as normas para tais casos e que tem a finalidade de submeter até que possivel o cônjuge ao seu direito nacional."

to BverfG, 22 de fevereiro de 1983, in BverfGE, 63, 181; in Iprax, 1983, 223; Ver a este respeito $\mathrm{HEIRINCH}$, cit. à nota 44; v. BAR, cit. à nota 51; Ver ainda SONNENBERGER, IPR-Reform und Verfassungswidrigkeit von Art. 15, ABS. 1 EGBG, in IPRax, 1984, $5 \mathrm{ss}$.

"O caso relativo ao regime de bens de unn casal no qual a mulher exa alemã, o marido no momento da celebração do matrimônio, iraquiano, mas foi mais tarde naturalizado. Depois da morte do marido, questionou-se se a

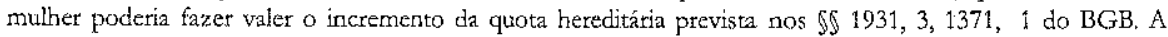
aplicação do estatuto de bens nesta questão pressupõe que a questão seja comumente qualificada como relativa ao regime patrimoníal. Ver STAUDINGER v. BAR, $12^{2}$ ed., 1983, art. 15, Rdz. 100-104.

${ }^{72}$ Ver sobre esse tema HELDRUCH, Zur Neubestimmung des Güterrechtsstatuts, in IPRax, 1984, 143 ss.; SCHURIG, Das Verhältnis von Staatsangehörigkeitsprinzip und Unwandelbarkeit im gegenwärtigen und künfrigen deutschen Ehegüterrecht, in JZ, 1985, p. 559 ss.; REINHART, cit. nota 61.

${ }^{73}$ Assim HELDRICH, cit. à nota precedente, p. 144; SONNENBERGER, cit. à nota 70, p. 7 ("limite do Rechtsfortidung possivel"); REINHART, cit. à nota 61, p. 100; A.A. SCHURIG, nota precedente.

${ }^{74}$ REINHART, cit. à nota 61, p. 99 com provas.

${ }^{75}$ REINHART, cit. á nota 61, p. 100-1001. O governo federal fez a seguinte proposta ná sún réplica à posição do conselho federal (BT-Drucksache 10/504 de 20 de outubro de 1983, p. 104 ss., 107); "Os efeitos da relação 
inclinado - por compreensíveis motivos de segurança jurídica ${ }^{76}$ - no sentido de conservar o regime de bens acordado na origem, fazendo referência à nacionalidade comum dos cônjuges, também quando a nacionalidade da esposa tenba sido adquirida apenas iure matrimonii, sem indagar-se a respeito da efetividade dessa nacionalidade ${ }^{77}$.

\section{III - O direito internacional do ilícito civil ${ }^{88}$}

O setor principal, no qual encontra aplicação o direito internacional do ilícito civil, diz tespeito aos acidentes de trânsito com conexão com o estrangeiro ${ }^{79}$. Os outros grupos de casos, mesmo sobre a responsabilidade do produtor $^{80}$ - passam ern segundo plano ${ }^{81}$. As normas alemãs escritas sobre os conflitos de leis conhecem apenas duas exceções, que são $o$ art. 12 do EGBGB e o $₫ 1^{\circ}$ do Rechtsanwendungsverordung (disposições sobre a aplicação da lei) de $1942^{82}$. Ambas prevêm o princípio da lex loci delicti. Segundo o art. 12 do EGBGB, não se pode fazer valer pretensões maiores por um ato ilícito cometido no estrangeiro por um alemão, das quais se estabelecem nas leis alemãs. O decreto sobre a aplicação do direito prevê a aplicação do diteito alemão para ilícitos cometidos no estrangeiro, quando tanto aquele que provocou o dano, como aquele que o sofreu, são alemães. O princípio da lex loci delicti foi contestado já há muito rempo: estabeleciamse uma "rigidez" do regime do ilícito ${ }^{83}$. O Bundesgerichtshof

patrimonial no matrimônio celebrado antes de 9 de abril de 1983, são regulados até 8 de abril de 1983 pelo direito daquele Estado de cujo o marido era cidadão no momento da celebração do matrimônio; pelo período sucessivo é aplicável o art 15, segundo o qual, o 09 de 1983 substitui o momento da celebtação do matrimônia Resta intacto o patrimônio dos cônjuges existente na data de 08 de abril de 1983,art. 15". Ver também v. BAR/IPSEN, Die Durchsettzung des Gleichberechtigungsgrundsatzes im internationalen Ehegüterrecht, in NJW, 1985, p. 2849 ss.

${ }^{76}$ Ver contudo MAGNUS, Verfassungswidrige Kollisionsnotmen und Vertrauensschuts, in NJW, 1982, p. $1922 \mathrm{~s}$.

${ }^{77}$ OLG Düsseldorf, 23 de dezembro de 1983, in IPRax, 1984, 156, LG Kempten, 3 de abril de 1984, in IPRax, 1985, 167.

${ }^{78}$ Ver este respeito HOHLOCH, Das Deliktstatut, 1984; LORENZ, Einige Überlegungen zur Reform des deutschen internationalen Delikstechts, in Festschrift Coing, 1982, p. 257 ss;; v. BAR, Grundlagen des internationalen Deliktsrechets, in JZ, 1985, p. 961 ss.

79 Ver HEPTING, "Gastarbeiterunfälle" in der neuesten Rechtsprechung zum internationalen Deliksrecht, in DAR, 1983, p. 97 ss.

\$) Ver este ponto BGH, 17 de março de 1981, in IPRax, 1982, 13, ver também KREUZER, Apfelschorf im "Alten Land" - Kollisionrechtliche Probleme der Produkthaftung, in MPRa, 1982, p. 1 ss. Nos Estados Unidos, ver JAYME, Produktenhftpflicht ausländischer Hersteller und internationale Zuständigkeit der Gerichte in Kalifornien, in IPRax, 1986, p. $193 \mathrm{~s}$.

${ }^{81}$ Sobre a responsabilidade por lesão a direito da personalidade, Ver LÜDERITZ, Ehrenshutz im internationalen Privatrecht, in NYW, 1692, 2142 ss.; HELDRICH, Persönlichkeitsverletzungen im internationalen Privatrecht, in CAEMMERER (ed.), Vorschläge und Gutachten zur Reform des deutschen internationalen Privatrechts der ausservertraglichen Schuldvehältnisse, 1983, p. 361.

${ }_{82}$ Com jurisprudência constante, o BGH reteve a persistente validade do decreto, conforme BGH, 2 de fevereiro de 1961, in BGHZ, 34, 222, 224 ss. Todavia são exceções da aplicação do decreto sobre ilícitos da concorrência desleal; Ver SCHRICKER, Etikettierung beim Weinexport und internationales Wettbewerbsrecht, in IPRAX, 1983, p. 103 ss, a p. 105.

"3 BINDER, Zur Auflocherung des Deliktsstatuts, in RabelsZ, 20 (1955), p. 401 ss. 
ateve-se, num primeiro momento - até onde foi possíve ${ }^{84}$ - ao princípio do lugar do ilícito. Apenas recentemente produziu tegras de direito internacional privado sobre o ilícito para dois importantes grupos de casos.

1 - A sentença de 8 de janeiro de 1985 tratava de um acidente de trânsito ocorrido em Portugal ${ }^{85}$. $\mathrm{O}$ autor era um cidadão alemão em viagem de férias; a demandada, ao contrário, a seguradora alemã de responsabilidade civil de um cidadão espanhol que vivia há 9 anos na Alemanha. A Corte Superior Federal (BGH) julgou ser aplicável o direito alemão e declarou o seguinte princípio:

"Quando, no caso de um acidente de trânsito, a residência habitual compartilhada pelo autor do dano e por aquele que o sofreu envia novamente a um ordenamento jurídico diferente daquele vigente no lugar do ilicito, e quando, considerando a nacionalidade, nenhuma das partes em causa tem relações com o estado no qual se encontra o lugar do ilícito, segundo o direito alemão dos conflitos de lei sobre a responsabilidade por ilícito e por risco, aplicar-seá o direito da residência habitual comum, no caso em que o causador e o sofredor do dano sejam Estados envolvidos no acidente com automóveis matriculados e assegurados no Estado de residência."

Esta evolução parcial para o princípio da residência habitual comum representa uma importante elaboração do direito intemacional da responsabilidade civil. Ainda no leading case de 5 de outubro de 1976 a Corte Federal tinha declarado:

"Nem o estatuto assegurador em comum, nem a comunidade da residência habitual fazem parecer "casual" o princípio do lugar do ilícito."

Todavia, no caso em espécie, a vítima do dano era cidadão do Estado no qual tinha ocorrido o acidente, razão pela qual as duas decisões não resultatam contraditónias.

Na nova sentença o Bundesgerichtshof-BGH podia apoiat-se nas propostas mais recentes de reforma ${ }^{87}$. Um peso particular competia ao projeto de lei para a integração do direito intemacional privado (relações obrigacionais extracontratuais e direitos teais) de 15 de maio de $1984^{88}$, que segundo

${ }^{84}$ Ver a este respeito HOHLOCH, Grenzen der Auflockerung des Tatotrpinzips im internationalen Delikrechts, in IPRax, 1984, P. 15 ss.

85 BGH, 8 janeiro 1985, in JZ, 1985, 441, nota W. LORENZ. Em primeira instância pronunciou-se o LG München, 3 agosto 1982, in IPRax, 1983, 244, nota VON HOFFMANN, em segunda instância O OLG München, 10 dezembro 1982, in VersR, 1984, 745, nota MANSEL. Ver A este respeito JAYME, Verkehrsunfälle in Portugal und deutsches internationales Deliktsrecht, Estudos em Homenagem ao Prof. Doutor Antônio de Arruda Ferrer Correia, Coimbra, 1986, p. 233 ss.

Bí BGH, 5 outubro 1976, in NJW, 1977, 496 ss., 498.

B7 Ver VON CAEMMERER, (ed,), cit. a nota 81.

${ }^{88}$ Trata-se do projeto, não publicado, do Ministétio Federal da Justiça. Tiveram restituições...... algumas partes, Ver SPICKHOFF, Zur Reform des deutschen internationalen Deliktsrechts, in VersR, 1985, 124 s; Ver Também BEIER/SCHRICKER/ULMER, Stellungnahme des Max-Planck-Instituts für ausländisches und internationales Patent-Urheber-und Wettbewerbsrecht zum Entururf eines Gesetzes zur Ergänzung des internationalen Privatrechts (áusservertragliche Schuldverhältnisse und Sachen), in GRUR Int., 1985, p. 104 ss. 
seu art. $40 \$ 2^{\circ}$, é determinante o direito daquele estado onde, no momento do acidente, tinham a própria residência habitual ou aquele que tem a obrigação de ressarcimento ou o que sofreu o dano.

2 - Para um grupo posterior de casos o Bundesgerichtshof in introduziu uma derrogação na regra do lugar do ilicito, a saber por uma familia de fato residente na Alemanha, que havia tido um acidente de trânsito durante uma viagem empreendida conjuntamente em um Estado com o qual não existiam outras relações. A sentença de 13 matço 1984 tratava de um acidente de trânsito ocorrido na Áustria. Todos os interessados eram cidadãos iugoslavos moradores na Alemanha em uma familia de fato ${ }^{\%}$. A Corte federal declarou a seguinte máxima:

"Quando, no caso de um acidente de trânsito, o lugar do ilícito, a residência habitual, seja do causador, seja do sofredor do dano, além da nacionalidade deles, levam respectivamente a ordenamentos juŕdicos diferentes, segundo o direito alemão dos conlitos de lei, é deteminante para a responsabilidade civil o direito da residência habitual cornum nos casos em que, durante a viagem, o causador e a vítima do dano tenham tido relações entre eles."

Talvez esses casos, e outros similares ainda, podem justificat-se também com um acordo tácito sobte direito do ilícito civil aplićável ${ }^{91}$.

3 - Na discussão que se desenvolve em todo o mundo em torno da nova definição do estatuto do ilícito civil, as normas materiais estiveram, antes de tudo, a exercitar uma influência predominante ${ }^{92}$. Tratava-se da exclusão da responsabilidade ou da limitação do ressarcimento dos danos à máxima garantita ${ }^{93}$; compaixão pela vítima do acidente tinha um efeito tal sobre as

${ }^{69}$ Consideração das normas de conflito na responsabilidade civil por questões considerando a famillia Ver JAYME, Interspousal Immunity: Revolution and Counterrevolution in American Tort Conflicts, in Southern California Law Review, 40 (1967), p. 307 ss. Aplicam o direito da residência conjugal: Potter v. St.Louis-San Francisco Ry. Co, 622 F2d 979, 981-983 (8th Cir. 1980); Robertson y McKnight 609 S. W. 2d 534 (Texas 1981); em sentido contrário McMillan v. McMillan, 253 S.E 2d 662 (Va. 1979); além disso no caso de compensação contra o cônjuge enquanto devedor solidário Krick v. Carter, 477, F. Supp. 152 (M.D Pa. 1979). Bons exemplos fornece a jurisprudência australiana, Ver Warren v. Warten (1972) Queensland Reports 386 (aplicada lex domicilii, o automóvel é registrado no estado de residência); Corcoran v. Corcoran, (1974), Victoria Reports 164 (Supreme Court of Victoria 1973) (aplicação enquanto satisfaz as pretensöes entre cônjuges, do direito de lugar de residência comum dos cònjuges onde também estava matriculado o automóvel no hugar da lex loci delicti do Novo Galles meridional); Ver A este respeito também PHEGAN, Tort Defences in the Conflict of Laws - The Second Condition of the Rule in Phillips v. Eyre in Australia, L. J, 1984, p. 24 ss, a, p. 35; NYGH, Conflict of Laws in Australia, 1984, p. 282 s.

\% $\mathrm{BGH}$, 13 março 1984, in BGHZ, 90, 294; in JZ, 1984, 669, nota V. BAR; analogamente Nevader v. Deyo, 489 N.Y.S. 2 d420 (App. Div. 1985) (cominiva de viagem composta de três pessoas entre as quais uma dupla de cônjuges de New York, acidente em Quebec, aplicável ao direito de New York).

91 Ver W. LOREN $\%$, cit. na nota 85.

12 Ver A este respeito EHRENZWEUG-JAYME, Private International Law, vol 3, 1977, p. 102 ss.

${ }^{13}$ Ver p. ex. Hurtado v. Superior Coutt of Sacramento Country, 522 P, $2 \mathrm{~d} 666$ (Cal. 1974) (a responsabilidade ilimitada do direito californiano impóe-se sobre a tesponsabilidade limitada do direito vigente no estado mexicano de Zacatecas). Analogamente ocorre tambérn que para a determinaçăo da jurisdiction; Ver Recentemente Pindeing v.National Broadcascing Corporation, 31 Canadian Cases on the Law of Torts, 251 ss., 261 (Ontario Supreme Court 1984): "the real advantage to the piainciff in bringing the 
regras de conflito, a ponto de estabelecer regras particulares que, mais ou menos abertamente, direcionavam a uma solução favorável ao sofredor do dano ${ }^{94}$.

No direito internacional privado alemão vige já o princípio que favorece a vítima nos casos em que o local do evento e o local das consequêencias se encontram em estados diferentes ${ }^{95}$. De outro lado, impressiona o fato de que a evolução para o princípio da residência nas duas sentenças mencionadas do Bundesgerichtshof encontrar-se em casos nos quais se tratava de ressarcimento de dano não patrimonial (dano moral).

Porém, a divergência dos ordenamentos jurídicos é considerável ${ }^{\% 6}$. Recentemente a Corte Suprema de Portugal, em uma sentença de 19 junho 1984, julgou adequado um ressarcimento do dano moral de 150.000 Escudos (ca. DM 3.000 = US 1.500) pela morte de uma criança de dois anos ${ }^{97}$ Parece injusta uma tal valoração para casos nos quais a família atingida não vive no estado do acidente. Aqui se põe a questão se nos casos internacionais, relativamente ao ressarcimento do dano moral, não se deveriam aplicar técnicas especiais do direito internacional privado. A Corte Federal, na sentença de 9 novembro 1965, considerou como ilícito a parte ter ocasionado dor aos parentes da vítima do acidente e como lugar das conseqüências aquele em que eles tiveram conhecimento disso (distribuição do aviso de falecimento $)^{9 \%}$. O lugar do acidente era a Itália, onde a filha da autora encontrara a morte: para o ressarcimento do dano moral, a Corte Federal aplicou o direito sú́ço. A meu ver, poder-seia genericamente sustentar uma conexão específica do ressarcimento do dano moral com o domicilio do interessado".

action in Ontario is that it is not necessary to establish "actual malice" ( $O$ autor era o Primeiro Ministro das Bahamas, enquanto a demandada era uma sociedade radiofônica americana com sede $\mathrm{cm}$ Delaware, o programa podia ser escutado também en Ontario).

94 Ver p. ex. Spearing v. Nacional Iron Co., $770 \mathrm{~F}$ 2d 87,92 (7th Cir. 1985: "... in doubtful conflict of laws situations Wisconsin prefers to give effect to its own policy of allowing the victim of an injury to recover common law damages..."; SEDLER, Rules of Choice of Law versus Choice-of-Law Rules: Judicial Method in Conflict Tort Cases, in Tenessee L Rev, 44 (977), 975 ss., 1034 ss. Ver também REESE, American Trends in Private International Law: Academic and Judicial Manipulation of Choice of Law Rules in Tort Cases, in Vanderbilt L. Rev, 33 (1980), 717 ss., $736 \mathrm{~s}$.

95 Sobre o principio da vantagem maior Ver v. BAR, cit na nota 78, p. 963 s.; OLG Saarbrücken, 22 outubro 1957 , in NJW, 1958, 752.

96 Ver p. ex. BÖHM, Der immaterielle Schaden in europäischen Reiseländem, in DAR, 1983, p. 116 ss,

"t Supremo Tribunal de justiça, 19 junho 1984, in B.M.J, NO. 338 (1984), 391.

98 BGH, 9 novembro 1965, in FamRZ, 1966,28 ss., 30-31; porém aqui, de qualquer modo, deveria-se levar em consideração o direito alemăo, sendo o demandado cidadão alemão (Art. 12 EGBGB).

9. Assim recentemente também v. BAR, cit. na nota 78, p968. Obtém-se um resultado análogo, se a determinação do ressarcimento dos danos motais é calculada entre as cláusulas de equuidade por meio das quais, como moral datum, é aplicável a lex forí (Ver MANSEL, in VersR 1984, p. 746 ss., 748); mas também os critérios referidos ao lugar de residencia da familia poderiam ser vistos como Local data a serrem considerados no âmbito da notma material do estatuto do illícito. Sobre a teoria dos dados ver: JAYME, cit, na nota 85; ver alérn disso OLG München, 10 dezembro 1982, in VersR, 1984, 745, 746. Para um exame sobre variadas técnicas de tratamento separado do ressarcimento dos danos morais Ver LORD WILBERFORCE, in Boys v. Chaplin (1971) A.C., 356, 384 ss., p. $392-393$ (acidente de dois 


\section{IV - O Direito Internacional dos Contratos}

O direito internacional dos contratos em 1986 é ainda em grande parte um direito consuetudinátio ${ }^{109}$. Jurisprudência e doutrina desenvolveram uma classificação de conexões. $O$ estatuto contratual é, em primeiro lugar, a lei escolhida pelas partes, com declaração expressa ou com um comportamento concludente. Na falta de uma escolha da lei, liga-se a assim chamada vontade hipotética das partes, que é individualizada sobre a base de um confronto objetivo de interesses ${ }^{101}$. "A âncota de salvação" (Kegel) ${ }^{102}$ é a conexão com o lugar da prestação que, todavia, no caso dos contratos a prestações correspectivas contratuais pode mostrat-se desvantajoso, conduzindo a uma cisão do estatuto contratual.

Agora, caso se questione qual tem sido a produção do direito internacional dos contratos por parte da jurisprudência alemã, parece-me que foi abandonado o critério de conexão baseado no lugar do cumprimento das respectivas obrigações a favor de um estado contratual unitário ${ }^{103}$.

A pedra de toque dessa evolução é a sentença da Corte Federal de 19 setembro $1973^{104}$. A autora era uma sociedade de Illinois que tinha comprado da ré alemã uma tetificadora para cilindros. O maquinário foi entregue nos EUA. A autora reclamava vícios e pedia o ressarcimento do dano. Estava em questão se seriam aplicáveis as normas alemãs $(\$ 477$ $\mathrm{BGB}, \S 377 \mathrm{HGB}$ ) sobre a prescrição e o dever de denúncia dos vicios do maquinário. Os júzes de primeiro e segundo grau e a Corte superior aplicaram a lei do vendedor e, com isso, o direiro alemão. A Corte federal, todavia, não se referia expressamente ao direito vigente na sede do vendedor, mas encontrava fundamento na vontade hiporética das partes para resolver o problema. Aqui, além da sede do vendedor, podem adquirir significado também outros momentos de conexão. Implica, pelo contrário, a negação da cisão do estaruto contratual:

"A importância de um estatuto contratual unitário com base na vontade hipotética das partes implica, por necessidade conceitual, que prevaleça o direito daquela parte em cujo campo de atividade encontra-se inequivocamente o fulcro espacial da relação contratual, e portanto o direito do vendedor quando ali está o fulcro."105

soldados ingleses em Malta; aplicado o direito inglês para a compensação de pain and suffering); para este caso Ver CARTER, Tort in English Private International Law, in The British Year Book of International Law, 1981, pp. 9 ss., 22 ss.

${ }^{130}$ MünchKomm/MARTINY, 1983, antes do Art. 12, RdNr.2.

${ }^{101}$ Provas em MünchKomm/MARTINY, 1983, antes do Art. 12, RdNr. 34 N. 139.

:02 KEGEL, Enternational Privarrecht, 1977, p. 295.

${ }^{103}$ Ver jâ BGH, 9 dezembro 1964, in BGHZ, 43, 21, 23: "À pergunta se um contrato tem sido cumprido não se pode dar resposta contrastante, desde que esteja en questão a obrigação de uma ou de outra patte do contrato"

${ }^{104} \mathrm{BGH}, 19$ setembro 1973, in BGHZ, 61, 221; in IIPRSpr, 1963, No. 11.

${ }^{105}$ IPRS 1973, No. 11, p. 32. 
O Bundesgerichtshof mencionava o projeto preliminar de um tratado da CEE de 6 dezembro $1972^{106}$ sobre as relações obrigacionais contratuais e extracontratuais, que faz prevalecer o direito do Estado no qual a parte que executa a prestação caracterizante tenha a própria residência habitual ou a própria sede. Esta regra encontra-se no Tratado de Roma da CEE sobre direito aplicável às relações obrigacionais contratuais, de 19 junho $1980^{107}$. A Corte Federal ilustrou o contraste com a jurisprudência anterior do Reichsgericht ${ }^{108}$ e com a mesma Corte ${ }^{109}$, pronunciando-se pela solução européia. A Rechtsfortbildung é feita sob a cobertura da referência a uma cláusula geral, a saber, a vontade hipotética das partes.

Depois dessa sentença, prevaleceu o estatuto contratual unitário ${ }^{110}$. A conexão com a prestação característica ou típica da profissão aparece hoje com maior frequiência na juriprudência ${ }^{111}$; todavia, não está ainda consolidada como norma jurídica.

\section{V - O Direito Transnacional}

Observando a Rechtforbildung do direito internacional privado, não se pode ignorar a questão de como interagem as regras de conflito estatais e o direito do comércio internacional

${ }^{106}$ Cfr para este projeto: SIEHR, Zum Vorentwurf eines EWG-Ubereinkommens über das Internationale Schuldrecht, in AWD, 1973, p. 569 ss.; LANDO, The EC-Draft Convention on the Law Applicable to Contractual and Non-Contractual Obligations, in abelsZ, 38 (1974), p. 6 ss.; FOYER, L'avant-projet de Convention C.E.E.sur la loi applicable aux obligations contractuelies e non contractuelles, in Clunet, $103(1976)$, p. 555 ss.

107 Art, 4: Ver a este respeito FALLON, Un"Restatement" européen du droit des confiits de lois en matière de contrats: la Convention de Rome du 10 juin 1980 sur la loi aplicable aux obligations contractuelles, in Assuntos Europeos (Lisboa), 1984, pp. 155 ss., 161 s.; LAGARDE, The European Convention on The Law Applicable to Contractual Obligations: An Apologia, in Virginia Journal of International Law, 22 (1981), p. 91 ss., a p. 97-98; JUENGER, The European Convention on The Law Applicable to Contractual Obligations: Some Critical Observations, in Virginia Jounarl of International Law, 22 (1981), p. 123 ss., a p. 132-143. JESSURUN D'OLIVEIRA, "Characteristic Obligation" in the Draft EEC Obligation Convention, in Am. J. Comp. L., 25 (1977), p. 303 ss., critica a conexão com a prestação caracterizante. Sobre os problemas conexos à defesa do consumidor Ver KROEGLR, Der Schutz der "marktschwächeren" Partei im Internationalen Vertragstecht, 1984, p. 168.

is RG., 28 abril 1900, in RGZ 46, 193, 195; RG., 19 abril 1910, in RGZ, 73, 379, 390; RG., 4 fevereiro 1913, in RGZ 81, 273, 275: "Pelo contrátio, não seria admissivel por exemplo etiquetar o direito do vendedor nos contratos de compra e venda como direito unitário só pelo motivo DE que a obrigação do vendedor de prestar a coisa é mais complexa do que a obrigação do adquirente de pagar o preço e mais facilmente dá início a controvérsias." A opiniano contrária se impóe sobre a "esfera social" do contrato; Ver SCFNITZER, Die Zuordnung der Verträge im internanonalen Privatrecht, in RabelsZ, 33 (1969), p. 17 ss., 23 s., IULIANO/LAGARDE, Bericht Recht, in Abl EG C 282 (31/10/1980), p. 20 (conexão com o ambiente "sócio-econômico").

:69 BGH, 14 fevereiro 1958, in NJW, 1958, 750; BGH, 9 junho 1960, in NJW, 1960, 1720.

:10 Recentemente o LG Hannover, 7 novembro 1985 - 16 S 17/85, declarou a prescrição do direito de um vendedor italiano pelo pagamento do preço da aquisição da parte de um adquirente alemão segundo o direito do ligar de cumprimento, a saber tramite os $\$ \$ 269,270$ BGB baseado no direito alemão. $O$ tribunal, todavia, não se ocupou da jurisprudéncia do BGH.

${ }^{11 t}$ Sobre o contrato de trabatho Ver AG Mainz, 23 fevereiro 1983, in IPRax, 1983, 299. 
"à formação espontânea". ${ }^{112}$ Aqui há interconexões problemáticas. A autonomia privada e os controles estatais ${ }^{11.3}$ podem entrar em colisão. A jurisprudência arbitral pode ser considerada um sismógrafo da internacionalidade. Talvez a decisão mais importante dos últimos tempos, que operou uma produção árdua de direito neste âmbito, venha dos Estados Unidos. É o caso Mitsubishi Motors Corporations v Soler Chrysler-Plymouth Inc. de 2 de julho de 1985. A sentença tratava da questão se as controvérsias sobre os cartéis podiam ser demandadas aos árbitros. A Suprema Corte dos Estados Unidos respondeu a esta questão de maneira afirmativa, contratiamente ao que até então vinha sendo decidido de forma unânime pela jurisprudência das cortes federais. ${ }^{114}$

O autor era um produtor japonês de automóveis, a requerida era uma sociedade de venda de Porto Rico. A sociedade autora era constituída como uma joint-venture, à qual eram associadas a suiça Chrysler Intemational e uma outra sociedade japonesa. $O$ contrato de venda continha uma cláusula compromissória segundo a qual todas as controvérsias deviam ser reguladas por um tribunal arbitral, no Japão, em conformidade com as normas da Associação Japonesa para os árbittos comerciais. A autora japonesa fez valer sua pretensão fundada no inadimplemento contratual e pediu o adimplemento da cláusula compromissória. O requerido propôs uma reconvenção fundada, entre outros motivos, sobre a norma antitrust do Sherman Act e sobre a norma de proteção de Porto Rico. ${ }^{115}$ A Supreme Court decidiu, em primeito lugar, que a cláusula devia ser interpretada, segundo a vontade das partes, de modo a incluir, também, as controvérsias que versassem sobre os cartéis, e, em segundo lugar, que esta cláusula era válida e eficaz segundo o Federal Arbitration Act. A Corte referia-se aquj à jurisprudência precedente que tinha reconhecido a eficácia de uma cláusula compromissória em um truly international agreement, embora tratasse de questões sujeitas ao Securities Exchange Act. ${ }^{16}$ A difícil questão se a corte arbitral teria, de qualquer modo,

\$2 Veja BONELL, Le regole oggettive dei commercio internazionale, 1976; STEFR, Sachrecht im IPR, transnationales Recht und lex mercatoria, in HOLL/KLINKE: (00), cito nota 3, p. 103 ss. Cfr. BONELL, Die Bedeutung der Handelsbriuche in Wiener Kaufrechtsübereinkommen von 1980, in J.B1., 1985, p. 385 ss; VON HOFFMANN, ciro nota 20; v. BAR, Typen des internationalen Einheitsrechts und das Internationale Privatrecht, in Recht und Wirtschaft (Osnabrücker Rechtswissensehaftliche Abhandlungen, vol. 1), 1985, p. 19 ss.; JAYME, Moderne Vertragsformen und klassisches lnternationales Privatrecht, in Heidelbetger Jahrbücher, XXIX $(1985)$, pP. 15 ss., 25 ss.

${ }^{113}$ Lake Communcatiosn, Inc. v. ICC Corpoxation, 738 F2d 1473, 1477 (9th Cir. 1984).

${ }^{114} 105$ S. Ct. 3346 (1985); os júzes STEVENS, BRENNAN e MARSHALI eram de uma dissenting opinion; ver sobre esse tema LANGEIWIESSNER, Die Schiedsfähigkeit intemationa/er Antitrust-Streitigkeiten, in RWW!AWD, 1985, p. 757 55. Ver também a decisão de segundo grau Mitsubishi Motor Corporation v. Soler Chrys/er-Plymouth, /nc., 723 F.2d 155 (1st Cir. 1983), refernte $\$ 91,1$ do GWB alemão (163).

${ }^{115}$ Lake Communications, Inc. v. ICC Corporation, 738 F. 2d. 1473, 1479 (9th Cir 1984) com muitas provas assim como comentáxios sobre o tratado de amizade americano-coreano com seria bom em 28 novembe 1956.

${ }^{116}$ Sobre os problemas de aplicação de noma inderrogável de proteção, mas os mediadores, ver a dissenting-opinion, 3374 (Automobile Dea/er's Day in Court Act, 15 V.S.C. $\$ 1$ 1221-1225), assim como, genericamente, KLEINSCHMIOT, Zur Amvendbarkeit zwingenden Rechts im internationalen Vertragsrecht unter besonderer Berücksichtigung von Absatzvermittlungsverträgen, München, 1985. 
aplicado o direito americano no tema dos cartéis - em particular, o contrato continha a escolha do direito suíço - foi colocada, pelo tribunal, em uma longa nota de rodapé. ${ }^{17}$

A Supreme Court americana supera assim, de muito, nos casos internacionais, a solução alemã do parágrafo $91,1 \mathrm{GWB}$, que considera nula as cláusulas compromissórias sobre questões nos temas envolvendo cartéis "quando não conferem a cada um dos interessados o direito de requerer, no caso concreto, a decisão de um tribunal ordinátio, ao invés daquela de um tribunal arbitral." No caso dos cartéis para exportação, porém, há a possibilidade de que a função dos cartéis enseje uma permissão.

A manifestação da Suprema Corte dos Estados Unidos deixa, segundo o Tratado de Nova Iorque sobre o reconhecimento e sobre execuções de sentenças arbitrais estrangeiras (1958), a possibilidade de recorrer durante a execução da sentença arbitral à ordre public nacional do Estado que confere o reconhecimento ${ }^{118}$ para salvaguardar assim o próptio direito antitrust. Além disso, abre uma outra perspectiva: a idéia de conceder uma nova ação no caso em que o tribunal arbitral não devesse tratar das pretensões relativas ao antitrust ${ }^{119}$. Por outro lado, a solução reforça, em grande medida, porém, o papel da autonomia das partes no direito comercial internacional com eventuais efeitos múltiplos ${ }^{120}$. Ao passo que recentemente o limite entre autonomia das partes e as nornas imperativas parecia posicionar-se a favor destas últimas ${ }^{121}$, contudo, agora, o pêndulo oscila em sentido oposto. O caso analisa a telação entre dois gigantes econômicos, Estados Unidos e Japão, mostrando, ao mesmo tempo, a particular atenção que

${ }^{117}$ Scherk v. Alberto-Culver Company, 417 V.S. 512, 515 (1974); ver sobre esse tema DIETRICH, Internationale Schiedsvereinbarungen vor amerikanischen Gerichten, in RabelsZ, 40 (1976), p. I 55. Por um entendimento similar da US-Supreme Court no caso de acordos internacionais sua jurisdição vedam $\mathrm{M} / \mathrm{S}$ Bremen v. Veja nota 129 , p. 3360. Da juxisprudência alemã cfr. BGH, 25 outubro 1966, in BGHZ 46, 365, 367 com provas posteriores; BGH, 27 fevereiro 1969, in WuW, 1969, 504 (WuW/E BGH, 1000); in BB 1969,461,692, nota P. ULMER; in ZZP, 84 (1971) 203, nota HABSCHEID (o artigo 85 do tratato CEE faz parte da "ordena pública").

${ }^{118}$ Aqui a US-Supreme Court faz sua idéia de sincronismo traz a competência e o direito aplicável: "We merely note that in the event of choice-of-forum and choice-of-clauses operated in tandem as a prospective waiver of a party's right 10 pursue statutory remedies for antitrust violations, we would have little hesitation in condemning the agreement as against public policy" (nota 133). De modo similar, mas em contexto diverso BGH, 12.03. 1984, in IPRax, 1985,216, e sobre esse tema ROTH, International zwingender Rechtsschutz: materiell und prozessual, in 1PRax, 1985, p. 198 ss.; HAUSERWELTER, Nalionale Gestallungsschranken bei ausländischen Borsentermingeschäften, in WM, 1985, $N^{\circ} 43$ de 26.10 .1985 .

11 Remontando à sentença Mitsubishi la V.S. Inlernalional Trade Commission abandonada sua pesquisa, a concorrência fica num caso em cujos interessados, una sociedade suíça $\mathrm{c}$ uma americana, havendo concordado, no contrato de licença, uma clásula arbitral segundo a qual a controvérsia deve sex composta com um procedimento arbitral da Câmara de Comércio Internacional. Certain Fluidized Bed Combustion Systems, Inv. NU 337-TA-213 (início em 14 dezembro 1984).

120 Ver, por exemplo, a sentença India BGH, 30 de maio de 1983 , in NIW, 1983, 2272, e sobre esse tema a critica de MANN, Die Gülugkeit der Rechtswahl - und Gerichtsstandsklausel und das internationale Privatrecht, in NIW, 1984. p. 2740 ss.

121 Ver, por cxemplo, as descriçôes aprofundada da estrutura de empresa multinacional japonesa in Bulova Walch Company inc. v. K. Hatlori \& C., Lid., 508, F. Supp., 1322 (E.D.N.Y. 1981). 
nos Estados Unidos é dedicada ao direito japonês ${ }^{122}$. O caso poderia, porém, adquirir importância também para as relações juridicas com a Europa e na Europa ${ }^{123}$.

\section{VI - Resumo e Observações Finais}

Observando "formas, papel e limites da Rechtsforbildung" do direito internacional privado, verificamos que o ponto de partida da Rechtsforbildung operada pelos juizes foi favorável. Regras de conflito incompletas e mais tardes declaradas inconstitucionais requeriam novas regras que - no silêncio do legislador-deviam ser criadas pela jurisprudência.

Os efeitos resguardam, de um lado a análise com a legislação nacional e de outro lado a estrutura do tráfego jurídico que se estende ao das fronteiras. As Rechtfortbildungen criadas em tempos recentes fizeram surgir a idéia que o legislador nacional possa ser supérfluo ${ }^{124}$; mas aqui, sob meu ponto de vista, apresenta, efetivamente, um perigo, porque o direito do "caso por caso" não deve substituir um sistema codificado aos fins da certeza do direito $^{125}$, e conrudo as modificações objetivamente necessárias podem ser tealizadas apenas em medida limitada. De outro lado, a jurisprudência orientou as próprias soluções sobre projetos de leis para um futuro direito internacional privado, considerando-se como "auxiliar" em uma fase de passagem entre as duas codificações. Visto no contexto internacional as soluções correspondem freqüentemente àquelas práticas ao exterior ${ }^{126}$.

No que se refere aos limites da Rechtfortbildung, a meu ver, o conteúdo residual do EGBGB permanece como uma barteira, como se observou quanto ao princípio da nacionalidade, que restou como ponto de partida para o desenvolvimento de novas soluções. Aa valorações operadas em pontos nodais das normas sobre conflitos de leis não as desfiguraram.

O papel ativo que a jurisprudência se afirmou no direito internacional privado. Isto significa, também, que o direito alemão autônomo dos conflitos de lei é hoje, em parte, o direito dos juízes (Richterrecht). Existe uma certa esperança que em virtude disso o legislador empreenda uma reforma parcial do direito internacional de família e parta, também, para o direito internacional privado ${ }^{127}$. Portanto, convida a algumas observações genéricas.

:22 Veja Bulova Watch Company Inc. v. K. Hattori \& C., Ltd, 508, F. Supp., 1322 (E.D.N.Y. 1981).

${ }^{123}$ Sobre a questão do recurso a tribunal arbitral internacional no caso de controvérsia no caso de controvérsia de sociedade de navegação aérea (caso Laker) ver REIMER, Zur Zuständigkeit von USGerichten bei internalionalen Streitigkeiten, in ZLW, 34 (1985), p. 130 ss.

${ }^{124} \mathrm{Um}$ "attimo di respiro" é de HELDRICH, cit. à nota 51, p. 1086.

125 Contra a codifrcação do direito internacional privado se pronuncia EHRENZWEIG, in Prospettive del diritto internazionale privato. Milano, 1968, p. 301 ss.

${ }^{i 26}$ Isso vale antes de tudo pela solução do direito internacional ao divórcio.

:27 O projeto de lei do governo federal (supra, nota 32) resguarda antes o direito contratual, mas a comissão CEE nutre dúvidas por uma tal revita ao Tratado de Roma de 19 junho 1980 (supra, nota 112), ver TPRax, 1985, 178 ss. 
Nos Estados Unidos persiste uma discussão que, de vez em quando, reascende-se sobre o papel da Supreme Court em uma democracia na qual devem ser verdadeiramente as leis aprovadas pela maioria para determinar o direito. Duas importantes monografias - de Ely ${ }^{128}$ e de Choper ${ }^{129}$ - foram recentemente elaboradas e, por vias divergentes, chegaram a resultados análogos. Nas legislações, o indivíduo é muito pouco representado; dificilmente o é em grau para impor seus interesses. O fim da judicial review, ou seja da formação judicial progressiva do direito como auxílio a Constituição, está, antes de mais nada, em proteger o direito das minorias e dos indivíduos, face a lei imposta pela maioria.

Transferindo este pensamento ao direito internacional privado alemão, e observando a reforma das leis que se busca a décadas, é fácil constatar que o direito internacional privado tem necessidade, particularmente, de atenção dos rribunais. O interesse político pelo direito internacional privado não é grande, contudo este setor jurídico, aparentemente um tanto distante, confunde-se não raramente com o direito dos estrangeiros. Nos setores do direito em cuja Rechtsfortbildung teve um grande papel, geralmente não se pode encontrar maioria para uma solução legislativa. No direiro internacional privado acontece o contrário. Uma cortesia desinreressada do legislador, ainda que difusa, faz que a legislação completa de direito internacional não seja algo urgente. As últimas sentenças da Conte Constitucional Federal ${ }^{130}$ parecem fazer sentir como uma pressão particular. $O$ indivíduo e o seu caso ao exterior são abandonados aos tribunais. Até mesmo o gigante econômico que determina suas próprias decisões aré os limires claros e unívocos da liberdade contratual fica sem resposta. Tanto mais agradecido deve-se ser às praxes que se adotam tão energicamente hoje para desenvolver soluções convincentes no campo internacional.

${ }^{128}$ ELY, Democracy and Distrust - A Theory of Judicial Review, 1980.

52 CHOPER. Judicial Review and the National Political Process - A Functional Reconsideration of the Role of the Supreme Court, 1980 (ed. de bolso 1983); do ponto de vista alemão, ver T. RAISER, Rechtssoziologische und rechtspolitische Bemer kungen zur richterlichen Rechtsbildung im Ziviltecht, in ZRP, 1985, p. 111 ss.

${ }^{130}$ Supra, notas $47,52,68$. 